\title{
Study of the effect of the application of an organic microelement complex on the yield and quality of field crops in the conditions of the Saratov Left Bank
}

\author{
Konstantin Denisov ${ }^{1, *}$, Ilia Poletaev ${ }^{1}$, and Konstantin Kondakov ${ }^{2}$ \\ ${ }^{1}$ Saratov State Agrarian University named after N.I. Vavilov, 410012, 1, Theatralnaya sq., Saratov, \\ Russian Federation \\ ${ }^{2}$ Design and Technology Institute of Sorghum and Corn Federal State Government-Funded Scientific \\ Institution, 410050, 4, 1 Institutskiy pr., Saratov, Russian Federation
}

\begin{abstract}
The article presents the materials of studies of effect of foliar application of organomineral fertilizers on the productivity and quality of agricultural crops grain in the conditions of dark chestnut soils of the Saratov Left Bank. It is shown that the application of an organic microelement complex (OMEK "Universal") contributes to an increase in yield at the level of $0.28 \mathrm{t} / \mathrm{ha}$ in winter wheat. of $0.07 \mathrm{t} / \mathrm{ha}$ in chickpeas and sunflower and of $0.23 \mathrm{t} / \mathrm{ha}$ in corn. Analysis of the product quality showed that after foliar fertilization with an organic microelement complex (OMEK "Universal"). these values were higher compared to the control and after application of Bionex-Kemi. When calculating the economic efficiency. the highest indicators of net income were after foliar application with fertilizer with an organic microelement complex (OMEK "Universal").
\end{abstract}

\section{Introduction}

One of the factors limiting the growth and development of plants is the nutritional regime. The reserves of available elements in the soil are often depleted or the rate of their assimilation is insufficient, which leads to a deficiency in plant nutrition. Each nutrient has its own significance and it is necessary to maintain a balance of macro- and microelements to obtain high and high-quality yields $[1,2,6]$.

Trace elements play an important role in the activation of enzymatic systems; they are part of pigments, hormones, vitamins and affect metabolic processes in plants, as well as they perform a number of other functions. With a lack of certain elements in plants, signs of their deficiency are found. However. an excess of such elements as $\mathrm{H}+, \mathrm{Cl}-, \mathrm{Al} 3+, \mathrm{Na}+, \mathrm{NH}^{+}$, $\mathrm{Pb} 2+, \mathrm{Sr} 2+, \mathrm{Cs}+$ can cause a number of non-infectious physiological plant diseases $[4,5]$.

Foliar application of mineral fertilizers is one of the ways to maintain the nutritional regime of cultivated plants. With the development of science, new fertilizers have been produced on the basis of organo-microelement complexes, but their effectiveness has been

* Corresponding author: k.denisov@inbox.ru 
little studied. In this regard, the purpose of the research was to study the effect of foliar application of an organic microelement complex on the yield and product quality of agricultural crops in the conditions of the Left Bank of the Saratov region.

\section{Methods}

The experiment was carried out in 2020, on the experimental field of the Saratov State Agrarian University named after N.I. Vavilov in the UNPO "Povolzhye", located in the Engels district of the Saratov region on dark chestnut medium-thick, medium loamy soil. The humus content is $2.8 \%$.

According to weather conditions, the year 2020 was characterized as moderately hot and dry, the amount of precipitation from April to August was $64.5 \mathrm{~mm}$. the hydrothermal coefficient was 0.25 , which is characterized as a dry year.

In total, $50.7 \%$ of the annual average precipitation fell during the growing season. April and May were characterized by temperatures below normal; in June and July, the temperature was 0.7 and $3.1{ }^{\circ} \mathrm{C}$ higher than the long-term average values. Throughout the growing season, the plants were law in moisture, which adversely affected their growth and development.

In order to study the effect of foliar application on the yield and grain quality in the conditions of the Saratov Left Bank, an experiment was laid to study the effect of foliar dressing with fertilizers on the growth and development of various cultivated plants.

Experiments included:

1. Winter wheat.

2. Chickpeas.

3. Sunflower.

4. Corn.

Experimental design:

1. Control (without foliar application).

2. Foliar application of Bionex-Kemi $(3 \mathrm{~kg} / \mathrm{ha})$.

3. Foliar application of OMEK "Universal" $(0.4 \mathrm{~kg} / \mathrm{ha})$.

Field experiment included observations and research in accordance with generally accepted methodological guidelines (Dospekhov B.A., 1985) [3].

The experiments were carried out in triplicate. The analysis of the crop yield was accounted by continuous combining.

The quality of the crop was determined in the educational and scientific testing laboratory on determination of the quality of food and agricultural products of the Saratov State Agrarian University named after N.I. Vavilov.

The mathematical processing of the experimental data was carried out by the ANOVA method using a computer according to B.A. Dospekhov (1985) [3].

The experiment included winter wheat (Novoershovskaya variety), chickpeas (Zoovit variety), corn (NK Falcon hybrid), sunflower (NK Bosphorus hybrid). Foliar application was carried out in accordance with the manufacturer's recommendation. The first foliar application on winter wheat was carried out in the tillering phase in a tank mixture with a herbicide (Balerina, 0.4 l/ha). The second foliar dressing was carried out in the heading phase with a tank mixture with an insecticide (Borey, $0.15 \mathrm{l} / \mathrm{ha}$ ). Chickpeas was treated in the bud phase - the beginning of flowering with a tank mixture with Borey insecticide $(0.15 \mathrm{l} / \mathrm{ha})$. Corn was treated in the phase of 5-7 leaves. The first foliar application on sunflower was carried out in the phase of three pairs of true leaves, the second application was carried out in the phase of the budding beginning. Treatments were carried out with a Tuman- 2 unit; the rate of consumption of the working solution was 200 1/ha. 


\section{Results and discussion}

Accounting for crop yields depending on the agricultural practices in 2020 showed that the application of fertilizers contributed to an increase in this indicator compared to the control variant.

Research on winter wheat showed that in the control variant, the yield was 3.43 tha. After foliar application of Bionex-Kemi fertilizer, this indicator increased by 0.21 t/ha $(6.12 \%)$ compared to the control and amounted to 3.64 t/ha. The application of OMEK "Universal" fertilizer increased the wheat yield by 0.28 tha $(7.69 \%)$ in comparison with the control.

Chickpeas treatment with fertilizers had a similar effect with winter wheat. In the control variant, the yield was $0.34 \mathrm{t} / \mathrm{ha}$. Foliar application of Bionex-Kemi increased it to $0.37 \mathrm{t} / \mathrm{ha}$, which is $0.03 \mathrm{t} / \mathrm{ha}(8.82 \%)$ higher than the control. The most effective treatment was the application of OMEK "Universal". The yield after its application was $0.41 \mathrm{t} / \mathrm{ha}$, the deviation from the control was 0.07 tha (18.92\%), Table 1 .

Table 1. Change in the yield of the studied crops during foliar feeding with the studied fertilizers, t/ha.

\begin{tabular}{|c|c|c|c|}
\hline \multirow[t]{2}{*}{ Variant } & \multirow[t]{2}{*}{ Yield. $t / h a$} & \multicolumn{2}{|c|}{$\begin{array}{c}\text { Increase in comparison with the } \\
\text { control }\end{array}$} \\
\hline & & t/ha & $\%$ \\
\hline & Winter wheat & & \\
\hline Control & 3.43 & - & - \\
\hline Bionex-Kemi & 3.64 & 0.21 & 6.12 \\
\hline OMEK "Universal" & 3.71 & 0.28 & 7.69 \\
\hline $\mathrm{LSD}_{05}$ & 0.013 & & \\
\hline $\mathrm{F}_{\text {fact }}$ & 103.8 & & \\
\hline \multirow[t]{2}{*}{$F_{\text {theor }}$} & 6.94 & & \\
\hline & Chickpeas & & \\
\hline Control & 0.34 & - & - \\
\hline Bionex-Kemi & 0.37 & 0.03 & 8.82 \\
\hline OMEK "Universal" & 0.41 & 0.07 & 18.92 \\
\hline $\mathrm{LSD}_{05}$ & 0.047 & & \\
\hline$F_{\text {fact }}$ & 8.5 & & \\
\hline \multirow[t]{2}{*}{$\mathrm{F}_{\text {theor }}$} & 6.94 & & \\
\hline & Corn & & \\
\hline Контроль & 1.50 & - & - \\
\hline Bionex-Kemi & 1.65 & 0.15 & 10.00 \\
\hline OMEK "Universal" & 1.73 & 0.23 & 13.94 \\
\hline $\mathrm{LSD}_{05}$ & 0.064 & & \\
\hline $\mathrm{F}_{\text {fact }}$ & 51.1 & & \\
\hline \multirow[t]{2}{*}{$\mathrm{F}_{\text {theor }}$} & 6.94 & & \\
\hline & Sunflower & & \\
\hline Control & 0.38 & - & - \\
\hline Bionex-Kemi & 0.40 & 0.02 & 5.26 \\
\hline OMEK "Universal" & 0.45 & 0.07 & 17.50 \\
\hline $\mathrm{LSD}_{05}$ & 0.026 & & \\
\hline $\mathrm{F}_{\text {fact }}$ & 29.2 & & \\
\hline$F_{\text {theor }}$ & 6.94 & & \\
\hline
\end{tabular}

The foliar application of the studied fertilizers on corn crops has shown that after application of Bionex-Kemi the differences were within the experimental error, while after application of OMEK "Universal" the yield was $1.73 \mathrm{t} / \mathrm{ha}$. Deviation from control was 0.23 t/ha (13.94\%).

In 2020, sunflower yield was low $(0.38 \mathrm{t} / \mathrm{ha})$ due to unfavorable weather conditions. The application of mineral fertilizers increased it within the range of 0.02-0.07 t/ha. The largest 
increase was after application of OMEK "Universal" fertilizer. Deviation from the control was $0.07 \mathrm{t} / \mathrm{ha}(17.5 \%)$. After application of Bionex-Kemi, this indicator was within the experimental error.

Obtained data evidence that under the influence of the studied factors, not only the yield of crops changes, but also the grain quality. Analyzes of the quality of winter wheat products showed that the grain in all variants contributed to the 1 st class of grain. After application of the OMEK "Universal" preparation, the protein content was higher than in the control by $1.68 \%$, gluten content - by $4 \%$. After application of Bionex-Kemi, these indices were slightly lower; the deviation from the control for protein was $0.57 \%$, for gluten $-3.5 \%$ (Table 2 ).

Determination of chickpeas grain quality showed that the protein content in the control variant was $23.81 \%$. After application of Bionex-Kemi, it increased by $0.36 \%$ or up to $24.17 \%$. This value was the highest after application of OMEK "Universal" - 26.19\%, which is $2.38 \%$ higher than the control. The fat and ash content was the highest after application of OMEK "Universal" - 4.2 and 3.39\%, respectively. After application of Bionex-Kemi, it was 3.9 and $3.27 \%$, respectively, while in the control variant, these indicators were 3.8 and $3.31 \%$, respectively (Table 3 ).

Table 2. Formation of the quality of winter wheat grain, depending on agricultural practices.

\begin{tabular}{l|c|c|c|c|c|}
\hline Variant & $\begin{array}{c}\text { Protein } \\
\text { weight } \\
\text { content, \% }\end{array}$ & $\begin{array}{c}\text { Deviation } \\
\text { from the } \\
\text { control, } \\
\text { absolute \% }\end{array}$ & $\begin{array}{c}\text { Gluten weight } \\
\text { content, \% }\end{array}$ & $\begin{array}{c}\text { Deviation } \\
\text { from the } \\
\text { control, } \\
\text { absolute \% }\end{array}$ & $\begin{array}{c}\text { Gluten } \\
\text { deformation } \\
\text { index }\end{array}$ \\
\hline Control & 14.88 & - & 33.5 & - & 72.0 \\
Bionex-Kemi & 15.45 & 0.57 & 37.0 & 3.5 & 68.5 \\
OMEK & 16.56 & 1.68 & 37.5 & 4.0 & 74.5 \\
"Universal" & &
\end{tabular}

Table 3. Change in chickpeas grain quality depending on agricultural practices.

\begin{tabular}{|l|c|c|c|}
\hline \multicolumn{1}{|c|}{ Variant } & $\begin{array}{c}\text { Protein weight } \\
\text { content, } \%\end{array}$ & $\begin{array}{c}\text { Fat weight } \\
\text { content, } \%\end{array}$ & $\begin{array}{c}\text { Ash weight } \\
\text { content, \% }\end{array}$ \\
\hline Control & 23.81 & 3.8 & 3.31 \\
Bionex-Kemi & 24.17 & 3.9 & 3.27 \\
OMEK "Universal" & 26.19 & 4.2 & 3.39 \\
\hline
\end{tabular}

Foliar application of studied preparations increased protein and starch weight content in the corn grain. In the control variant, these indicators were equal to 12.56 and $65.13 \%$, respectively. After application of Bionex-Kemi they increased to 13.25 and $65.72 \%$, respectively, which is higher than the control by 0.69 and 0.59 abs. \%. The protein weight content after application of OMEK "Universal" was equal to the Bionex-Kemi indicator, and the starch content was the highest among the variants of the experiment and amounted to $66.84 \%$, which is $1.71 \%$ higher than in the control variant (Table 4 ).

Table 4. Quality of corn grain, depending on agricultural practices.

\begin{tabular}{|lcc|}
\hline \multicolumn{1}{|c}{ Variant } & $\begin{array}{c}\text { Protein weight content, } \\
\mathbf{\%}\end{array}$ & $\begin{array}{c}\text { Starch weight } \\
\text { content, } \%\end{array}$ \\
\hline Control & 12.56 & 65.13 \\
Bionex-Kemi & 13.25 & 65.72 \\
OMEK "Universal" & 13.25 & 66.84 \\
\hline
\end{tabular}

Analysis of sunflower grain for oil content and acid number showed that after application of OMEK "Universal" the sunflower grain contributed to the first class of quality. In the control variant and after application of and Bionex-Kemi it contributed to the second quality class. Oil content of sunflower in the control variant was $45.9 \%$, after application of Bionex- 
Kemi, it increased to $48.2 \%$ (2.3 abs. \%), after application of OMEK "Universal" it increased to $57 \%$ (11.1 abs. \%) compared to the control. The oil acid number decreased from $0.6 \mathrm{mg}$ $\mathrm{KOH} / \mathrm{g}$ in the control to $0.3 \mathrm{mg} \mathrm{KOH} / \mathrm{g}$ after application of Bionex-Kemi. After treatment with OMEK "Universal", this indicator was the lowest and amounted to $0.1 \mathrm{KOH} / \mathrm{g}$ (Table $5)$.

Table 5. Quality of sunflower grain, depending on agricultural practices.

\begin{tabular}{l|c|c|}
\hline \multicolumn{1}{|c|}{ Variant } & $\begin{array}{c}\text { Oil content on } \\
\text { dry basis, \% }\end{array}$ & $\begin{array}{c}\text { Oil acid number, } \\
\text { mg KOH/g }\end{array}$ \\
\hline Control & 45.9 & 0.6 \\
Bionex-Kemi & 48.2 & 0.3 \\
OMEK "Universal" & 57 & 0.1 \\
\hline
\end{tabular}

The analysis of the economic efficiency of the studied agricultural practices showed that in all variants the conditional net income from the application of OMEK "Universal" fertilizer exceeded the variant with the Bionex-Kemi treatment (Table 6).

Table 4. Economic efficiency of the studied agricultural practices.

\begin{tabular}{l|c|c|c|c|}
\hline Fertilizer & $\begin{array}{c}\text { Increase in } \\
\text { yield after } \\
\text { foliar } \\
\text { dressings, } \\
\text { t/ha }\end{array}$ & $\begin{array}{c}\text { The cost of } \\
\text { foliar } \\
\text { dressing, } \\
\text { thousand } \\
\text { rubles/ ha }\end{array}$ & $\begin{array}{c}\text { The cost of } \\
\text { additionally } \\
\text { received products, } \\
\text { thousand rubles/ha }\end{array}$ & $\begin{array}{c}\text { Conditional net } \\
\text { income after } \\
\text { foliar dressing, } \\
\text { thousand } \\
\text { rubles/ha }\end{array}$ \\
\hline $\begin{array}{l}\text { Bionex-Kemi } \\
\text { OMEK }\end{array}$ & 0.21 & 0.36 & 3 \\
"Universal" & 0.28 & 0.28 & 3.36 & 4.2 \\
Bionex-Kemi & 0.03 & 0.36 & 4.48 & 0.54 \\
OMEK & 0.07 & 0.28 & 0.9 & 1.82 \\
"Universal" & & Chickpeas & 2.1 & 1.74 \\
Bionex-Kemi & 0.15 & 0.36 & 2.1 & 2.94 \\
OMEK & 0.23 & 0.28 & 3.22 & 0.34 \\
"Universal" & & Sunflower & & 2.17 \\
Bionex-Kemi & 0.02 & 0.36 & 0.7 & \\
OMEK & 0.07 & 0.28 & 2.45 & \\
"Universal" & & & & \\
\hline
\end{tabular}

Regarding winter wheat, the conditional net income after application of OMEK "Universal" was 4.2 thousand rubles/ha, while after application of Bionex-Kem - 3.0 thousand rubles/ha. This is due to the low cost of OMEK "Universal" in comparison with Bionex-Kemi and a higher increase in yield. Similar indicators are noted in chickpeas, corn and sunflower sowings.

\section{Conclusion}

According to the results, the most effective application of foliar feeding was in chickpeas and sunflowers sowings, the increase in yield from was 5.26-18.92\% in severely arid conditions. The greatest increase in the yield was after application of OMEK "Universal". It ranged from 7.69 to $18.92 \%$. OMEK "Universal" application was the most effective in chickpeas and sunflower sowings. 
Grain quality indicators were higher after application of OMEK "Universal" in winter wheat sowings. The protein content was higher than in the control variant by $1.68 \%$ and gluten content - by $4 \%$. According to the protein content, gluten and gluten deformation index, the grain in all variants contributed to the first class of grain quality. Indicators of the weight content of protein, fat and ash in chickpeas sowings were the highest afetr application of OMEK "Universal" - 26.19, 4.2 and 3.39\%, respectively.

In corn grain, the starch content was the highest after application of OMEK "Universal", it amounted to $66.84 \%$, which is $1.71 \%$ higher than in the control variant. After application of OMEK "Universal", sunflower belonged to the first class of grain quality in the control variant and to the second quality class after application of Bionex-Kemi.

The calculation of economic efficiency has shown that the treatment with the studied fertilizers allows one to get a net income in all studied crops, but the greatest economic effect was after application of OMEK "Universal" fertilizer.

\section{References}

1. V. V. Glukhovtsev, N. V. Sanina, Izvestiya of the Orenburg State Agrarian University, 60, 4 (2018)

2. E. P. Denisov, A. P. Solodovnikov, B. Z. Shagiev, D. S. Stepanov, I. S. Poletaev, A. O. Kudashova, Agrarian scientific journal, 4 (2018)

3. B. A. Dospekhov, Methodology of field experience (with the basics of statistical processing of research results)(Moscow, 1985)

4. A. I. Pryanishnikov, et al., Achievements of science and technology of the agroindustrial complex, 11 (2010)

5. D. Akin, L. Rigs, Agron. J., 77, 1 (1985)

6. M. D. Owen, I. A. Zelaya, Herbicide-resistant Crops from Biotechnology, 61 (2015)

7. D. Abol-Fotouh, M. A. Hassan, H. Shokry, A. Roig, M. S. Azab, A. E. Kashyout, Scientific Reports, 10, 1 (2020)

8. C. Amor, L. Marchão, M. S. Lucas, J. A. Peres, Water (Switzerland), 11, 2 (2019)

9. R. R. C. Bastos, A. P. da Luz Corrêa, P. T. S. da Luz, G. N. da Rocha Filho, J. R. Zamian, L. R. V. da Conceição, Energy Conversion and Management, 205 (2020)

10. D. Carrillo-Nieves, M. J. Rostro Alanís, R. de la Cruz Quiroz, H. A. Ruiz, H. M. N. Iqbal, R. Parra-Saldívar, Renewable and Sustainable Energy Reviews, 102 (2019)

11. A. M. Girelli, M. L. Astolfi, F. R. Scuto, Chemosphere, 244 (2019)

12. R. S. Singh, N. Kaur, J. F. Kennedy, Carbohydrate Polymers, 217 (2019)

13. M. Wakkel, B. Khiari, F. Zagrouba, Journal of the Taiwan Institute of Chemical Engineers, 96 (2019) 